\title{
YOUTH CENTER DI KOTA PONTIANAK
}

\author{
Dita Ollivia Artha ${ }^{1}$, Bontor Jumaylinda BR Gultom², Emilya Kalsum ${ }^{3}$ \\ ${ }^{1}$ Mahasiswa, Program Studi Arsitektur, Fakultas Teknik, Universitas Tanjungpura. \\ olliviadita20@gmail.com \\ ${ }^{2}$ Program Studi Arsitektur, Fakultas Teknik, Universitas Tanjungpura \\ ${ }^{3}$ Program Studi Arsitektur, Fakultas Teknik, Universitas Tanjungpura
}

Naskah diajukan pada: 30 Januari 2021

Naskah revisi akhir diterima pada: 3 Februari 2021

\begin{abstract}
Abstrak
Remaja merupakan periode perkembangan dari anak-anak menuju dewasa. Remaja memiliki beragam karakteristik dalam perkembangannya. Kurangnya fasilitas dan pembinaan pada remaja menyebabkan muncul perilaku kenakalan remaja, sedangkan masa remaja merupakan masa yang sangat penting karena terjadi proses pembentukan karakter individu. Remaja memerlukan wadah yang dapat membina dan mengembangkan potensinya. Wadah yang berorientasi pada remaja yaitu Youth Center. Perancangan Youth Center harus memfasilitasi fungsi bangunan dengan tetap memperhatikan karakteristik remaja di Kota Pontianak. Perancangan Youth Center menggunakan metode deskriptif yaitu pemaparan mengenai literatur dan teori. Adapun tahapan dalam metode perancangan diawali dengan mengumpulkan data, kemudian data dianalisis hingga membentuk konsep yang menghasilkan produk berupa gambar perancangan. Perancangan Youth Center di Kota Pontianak memiliki fungsi kreatif, reakreatif dan edukatif. Lokasi perancangan berada di persimpangan Jalan A. Yani dan Jalan MT. Haryono dengan luas $\pm 5.877 \mathrm{~m}^{2}$. Bangunan terdiri dari empat lantai, lantai satu terdiri dari ruang yang bersifat publik, lantai dua berisi area olahraga, kemudian pada lantai tiga terdapat area bermain, sedangkan pada lantai empat terdiri dari ruang-ruang yang bersifat edukatif. Hasil yang dicapai yaitu perancangan bangunan berdasarkan fungsi bangunan dengan berlandaskan aktivitas serta karakteristik remaja di Kota Pontianak.
\end{abstract}

Kata-kata Kunci: Remaja, Karakter Remaja, Youth Center

\begin{abstract}
Adolescence is a period of development from children to adults. Adolescents have various characteristics in their development. Lack of facilities and guidance for adolescents causes juvenile delinquency behavior, while adolescence is a very important period because of the process of forming individual characters. Youth need a place that can nurture and develop their potential. Youth-oriented forum, namely the Youth Center. The design of the Youth Center must facilitate the function of the building while taking into account the characteristics of youth in Pontianak City. The design of the Youth Center used a descriptive method, namely the description of literature and theory. The stages in the design method begin with collecting data, then the data is analyzed to form a concept that produces a product in the form of a design image. The design of Youth Centers in Pontianak City has creative, reacreative and educational functions. The design location is at the intersection of A. Yani street and MT. Haryono street with an area of $+5,877 \mathrm{~m} 2$. The building consists of four floors, the first floor consists of public spaces, the second floor contains a sports area, then on the third floor there is a play area, while the fourth floor consists of educational spaces. The results achieved were building design based on building functions based on the activities and characteristics of youth in Pontianak City.
\end{abstract}

Keywords: Youth, Youth Character, Youth Center

\section{Pendahuluan}

Remaja merupakan generasi penerus bangsa yang berperan penting dalam pembangunan bangsa Indonesia, hal ini didukung dengan adanya pernyataan dari Holger Kohl, professor dari 
Universitas Berlin (Media Indonesia, 2018), yang mengatakan bahwa dalam kurun waktu 15 tahun mendatang Indonesia akan menikmati masa bonus demografi ketika penduduk didominasi oleh usia produktif/remaja.

Remaja adalah masa peralihan dari kanak-kanak menuju dewasa, terdapat beberapa karakteristik yang terjadi pada remaja dalam proses perkembangannya. Menurut Bappenas (2013), sekitar $68,7 \%$ penduduk Indonesia merupakan penduduk usia remaja. Hal tersebut juga terjadi di Kota Pontianak, dimana sekitar $25 \%$ penduduk di Kota Pontianak merupakan remaja.

Remaja di Kota Pontianak umumnya melakukan aktivitas di dalam dan di luar lingkungan sekolah, kegiatan yang terjadi di luar lingkungan sekolah dilakukan dengan mengikuti kegiatan yang terdapat pada suatu komunitas.

Kurangnya pembinaan serta fasilitas yang berorientasi pada remaja kerapkali menyebabkan terjadinya perilaku menyimpang pada remaja. Terdapat beberapa penyimpangaan yang sering terjadi pada remaja di Kota Pontianak, diantaranya yaitu penyalahgunaan narkoba (BNN Kalbar, 2019), seks pranikah (Suwarni, 2009) dan tawuran (Kartono, 2006). Sedangkan menurut Ahmadi dan Uhbiyati (2001) masa remaja merupakan masa yang sangat penting, karena pada tahapan ini terjadi pengembangan karakter dan tahap awal pembentukan keperibadian remaja, sehingga perlu adanya pembinaan terhadap remaja karena pada masa ini remaja perlu mepersiapkan diri untuk masa mendatang sehingga perlu adanya sarana yang dapat membina serta menunjang perkembangan diri remaja ke arah yang positif.

Tahun 2004 di Kota Pontianak telah terdapat wadah khusus bagi remaja untuk mengambangkan potensinya yaitu Gedung Arena Remaja. Namun saat ini gedug tersebut telah dialihfungsikan serta mengalami perubahan desain serta perubahan nama menjadi Pontianak Convention Center (PCC) sehingga saat tidak terdapat wadah khusus yang berorientasi pada remaja.

Saat ini remaja di Kota Pontianak melakukan aktivitasnya pada area-area publik seperti kawasan olahraga, taman-taman dan Jalanan, sehingga tidak bersifat representatif. Menurut Kamus Lengkap Bahasa Indonesia (1991) wadah yang digunakan remaja untuk memanfaatkan waktu luang dengan melakukan kegiatan yang positif disebut Gelanggang Remaja. Kemudian menurut KBBI (2008) Gelanggang Remaja merupakan tempat yang disediakan sebagai fasilitas hiburan dan kreatifitas. Selain itu menurut Perda Kota Pontianak Nomor 3 Tahun 2018, Gelanggang Remaja merupakan salah satu sarana pendidikan yang bersifat non formal.

Perancangan Youth Center di Kota Pontianak berfungsi untuk mewadahi serta mengembangkan potensi remaja di Kota Pontianak, sehingga dalam proses perancangannya akan berlandaskan pada fungsi bangunan yang dikomparasikan dengan karakteristik remaja Kota Pontianak, sehingga hasil yang akan dicapai dapat sesuai dengan kebutuhan remaja.

\section{Kajian Pustaka}

Youth Center memiliki makna yang sama dengan Gelanggang Remaja sehingga tinjauan pustaka Youth Center menggunakan standar penyelenggaraan Gelanggang Remaja yang berpedoman pada standar peraturan Indonesia.

Menurut WHO (1974) remaja merupakan suatu masa ketika seseorang mengalami perkembangan psikologis serta perkembangan pola identifikasi dari kanak-kanak menjadi dewasa. Kemudian Menurut Sarwono (2004) dalam bukunya yang berjudul Psikologi Remaja, remaja merupakan penduduk dengan batasan usia 11 - 24 tahun. Terdapat perilaku yang kerap terjadi pada remaja menurut Lewin (1946) yakni perilaku pemalu, perasa, cepat marah, agresif, radikal, memberontak serta perilaku lain yang ditentukan oleh sifat dan kekuatan individu, hal ini didukung dengan adanya pernyataan dari Jatmika (2010) yang mengatakan bahwa pada dasarnya remaja memiliki berbagai karakteristik pada dirinya.

Remaja merupakan individu yang berkembang, hal ini ditandai dengan adanya kebutuhan yang 
perlu dipenuhi dalam perkembangannya, menurut Edward dalam Argiati (2008) terdapat beberapa kebutuhan pada remaja yaitu kebutuhan akan keteraturan, pencapaian dan kebutuhan untuk bergaul. Selain kebutuhan, remaja juga memiliki minat dalam dirinya, minat tersebut menurut Krori (2011) meliputi keinginan untuk rekreasi, ketertarikan dalam menjalin hubungan sosial, serta minat vokasional dan minat dalam simbol maupun status. Selain memiliki kebutuhan serta minat, menurut Gunarsa (2001) terdapat berbagai karakteristik pada remaja yang terjadi dalam proses perkembangannya, Gunarsa membagi remaja dan karakteristiknya menjadi tiga periode yaitu masa remaja awal, masa remaja madya dan masa remaja akhir.

Selain menginginkan hal-hal positif, remaja pada umumnya seringkali melakukan kesalahan dalam perkembangannya, adapun kesalahan yang ditimbulkan oleh remaja (Gunarsa (1982) meliputi adanya kesenangan bereksperimen terhadap hal baik maupun buruk, memiliki ketidakstabilan emosional serta memiliki perasaan gelisah dan ragu dalam mengambil tindakan. Sehingga dengan adanya permasalahan tersebut, remaja harusnya dapat bertindak tegas dalam mengambil suatu tindakan karena akan berdampak pada masa depan remaja. Menurut Hurlock (1990) terdapat beberapa hal yang perlu dilakukan remaja dalam menjalani proses perkembangannya, hal tersebut mmeliputi harus adanya kesiapan remaja untuk menerima dan memanfaatkan kondisi fisik secara efektif sehingga remaja dapar bertanggung jawab dalam setiap tingkah lakunya dan dapat mempersiapkan diri untuk masa depan. Youth Center di Kota Pontianak akan dikelola oleh Dinas Kepemudaan, Olahraga dan Pariwisata (DISPORAPAR) karena merupakan sarana pendidikan non formal yang dikelola oleh pemerintah.

Berdasarkan Pedoman Penyelenggaraan Gelanggang Remaja (1989), Fungsi Gelanggang Remaja yaitu sebagai penyediaan sarana yang mencakup bidang ilmu pengetahuan dan keterampilan, olahraga, mental spiritual, seni dan berkreasi. Sasaran utama dikhususkan bagi penduduk dengan kelompok usia remaja dengan mewadahi kegiatan yang umumnya berada di indoor dan outdoor dan kegiatan yang diadakan ialah untuk mengisi waktu luang. Terdapat tiga klasifikasi Gelangga Remaja yaitu Gelangga Remaja tipe A (skala kecamatan), Tipe B (skala kota), dan Tipe C (skala provinsi).

\section{Metode}

Metode perancangan merupakan suatu alat yang digunakan untuk mengetahui suatu hasil melalui beberapa tahapan yang teratur dan sistematis. Adapun tahapan-tahapan yang dilakukan dalam perancangan Youth Center yaitu tahap gagasan, tahap tinjauan teoritis, tahap pengumpulan data, tahap analisis, tahap sintesis, tahap pra rancangan dan tahap pengembangan rancangan. Tahap gagasan merupakan tahap persiapan berisi latar belakang serta tujuan perancangan. Tahap tinjauan teoritis membahas mengenai teori yang berhubungan dengan perancangan meliputi fungsi, ciri, kasifikasi serta jenis kegiatan. Tahap pengumpulan data dilakukan dengan mempersiapkan alat dan bahan yang diperlukan, alat dan bahan yang perlukan, adapun data yang perlu dianalisa yakni data sekunder. Tahap analisis merupakan tahap menganalisis infromasi yang telah diperoleh yang kemudian dirangkum untuk diolah pada tahapan selanjutnya. Tahapan sintesis merupakan kesimpulan dari analisis yang dilakukan sehingga membentuk konsep pemecahan masalah yang akan di aplikasikan dalam tapak Youth Center. Tahap Pra Rancangan merupakan tahapan penerapan sintesis atau desain yaitu usulan keputusan pemecahan masalah yang bersifat sementara. Kemudian tahap pengembangan perancangan, tahap ini merupakan tahapan final atau keputusan akhir pemecahan masalah desain Youth Center yang kemudian akan menjadi dasar untuk merancang detail.

\section{Hasil dan Pembahasan}

Youth Center merupakan sarana pendidikan non formal, sarana pendidikan non formal merupakan bagian dari fasilitas sosial yang dikelola oleh pemerintah, sehingga bangunan Youth Center akan dikelola oleh Dinas Kepemudaan, Olahraga dan Pariwisata. Adapun pemilihan lokasi Youth Center sebaiknya berada dalam kawasan yang dikelola ataupun memiliki kedekatan dengan fasilitas DISPORAPAR sehingga Youth Center dapat menunjang eksistensi kawasan. 
Lokasi perancangan Youth Center di Kota Pontianak berada di Jalan Ahmad Yani, Kelurahan Akcaya, Kecamatan Pontianak Selatan, Kota Pontianak, Kalimantan Barat. Berdasarkan Perda No 2 Tahun 2013 tentang RTRW Kota Pontianak Tahun 2013-2033, peruntukan wilayah yaitu kawasan perdagangan dan jasa. Lokasi memiliki luas $\pm 5.877 \mathrm{~m}^{2}$, KDB maksimal $80 \%$, KLB maksimal 9, $\mathrm{KDH}$ minimal $10 \%$ dan terdapat jaringan Jalan arteri. Lokasi perancangan Youth Center di Kota Pontianak dapat dilihat pada Gambar 1.

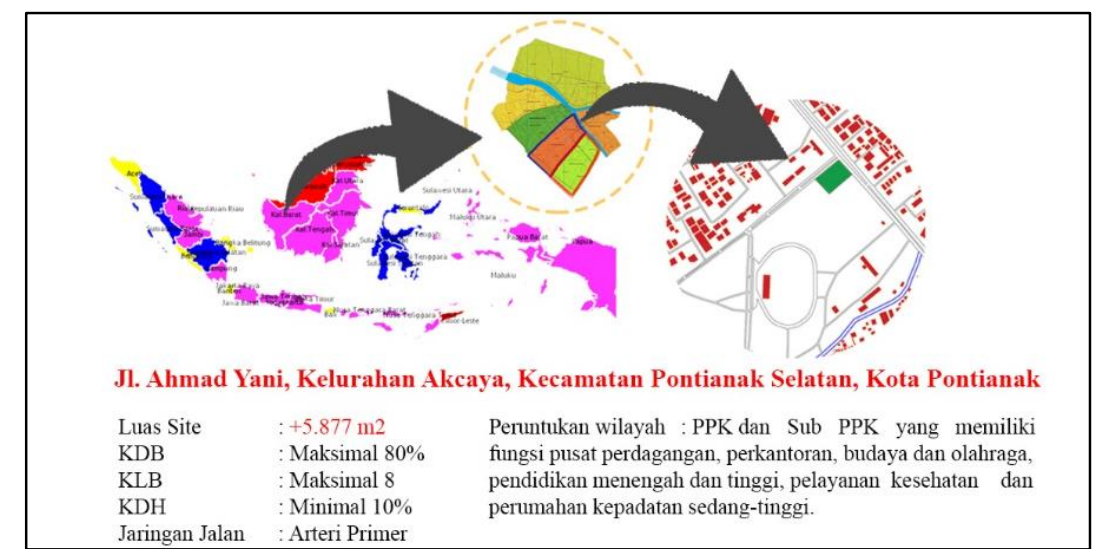

Gambar 1. Lokasi Perancangan Youth Center di Kota Pontianak

Sumber: Penulis, 2020

\section{Landasan Konseptual}

Landasan Konseptual merupakan proses analisa untuk menghasilkan konsep perencanaan dan perancangan Youth Center di Kota Pontianak. Proses analisa meliputi analisa fungsi bangunan, internal, eksternal, gubahan bentuk, struktur, utilitas dan fisika bangunan.

Fungsi bangunan dirumuskan berdasarkan teori yang direlevankan terhadap aktivitas yang terjadi pada komunitas remaja di Kota Pontianak. Fungsi terdiri dari tiga yaitu fungsi edukasi, fungsi rekreasi dan fugsi kreatifitas. Fungsi edukasi meliputi kegiatan yang berhubungan dengan pengembangan pengetahuan, sedangkan fungsi rekreasi berhubungan dengan kegiatan yang bersifat santai untuk mengisi waktu luang dan refreshing, kemudian fungsi kreatifitas berhubungan dengan pengembangan keterampilan remaja

Pelaku bangunan Youth Center di Kota Pontianak mengacu pada aktivitas yang terjadi di dalam bangunan, pelaku yaitu komunitas, konselor, pengunjung, penyewa, narasumber, instruktur, pengajar dan pengelola. Komunitas merupakan remaja yang tergabung dalam komunitas serta remaja yang sekedar mengikuti kegiatan namun belum terdaftar sebagai anggota komunitas juga disebut sebagai pelaku komunitas. Konselor merupakan pelaku yang bertugas memberikan bimbingan konseling. Kemudian pengunjung merupakan pelaku yang datang untuk menikmati atau menonton pertunjukan. Seletah itu, penyewa merupakan pelaku yang datang untuk menyewa ruangan. Narasumber, instruktur dan pengajar merupakan pelaku yang diundang untuk memberikan seminar, pengajaran maupun pelatihan pada pelaku komunitas. Kemudian pelaku pengelola merupakan pelaku yang mengatur maupun memelihara bangunan Youth Center di Kota Pontianak.

Kebutuhan ruang Youth Center di Kota Pontianak berjumlah 57 ruang, yang terdiri dari post satpam, lobby, retail peralatan olahraga, retail souvenir, ruang penyewaan sepeda, ruang seminar, lounge, resepsionis, ruang rapat, ruang kepala, ruang tata usaha, ruang staff pelayanan, ruang staff srana dan prasarana, ruang tamu, aula serbaguna, perpustakaan, area berkumpul, area bermain, ruang seni beladiri, ruang tenis meja, ruang bulu tangkis, ruang fitness dan aerobic, ruang panahan, area outbond indoor, area panjat tebing indoor, ruang tunggu, ruang computer, Ruang Belajar, ruang konseling, studio musik, studio fotografi, ruang desain, ruang belajar desain, ruang arsip, ruang 
monitoring, ruang audiovisual, ruang ganti, ruang bilas, pantry, ruang wudhu, mushola, janitor, Ruang Keamanan, R. AHU, R. Panel, Gudang, Ruang Sound System \& CCTV, ruang ME, dan toilet. Total luas kebutuhan ruang yaitu $8.577,91 \mathrm{~m}^{2}$.

Analisis tapak Youth Center di Kota Pontianak terbagi mejadi konsep tapak sirkulasi, konsep tapak perletakan, konsep tapak orientasi, konsep tapak vegetasi, dan konsep tapak zonasi. Analisa sirkulasi (poin 1) menghasilkan entrance utama bangunan yang terletak di Jalan A.yani dengan pertimbangan Jalan A.yani merupakan Jalan utama kawasan yang berpotensi besar dilalui kendaraan, untuk second entrance berada di Jalan MT. Haryono dengan pertimbangan kemacetan rendah. Untuk entrance keluar bangunan terdapat di Jalan MT. Haryono (lihat Gambar 2).

Hasil dari analisa konsep tapak perletakan (poin 2) yaitu perletakan bangunan dimundurkan dari Jalan A.yani dan Jalan MT. Haryono untuk mereduksi kebisingan serta polusi dari kendaraan. Area terluar bangunan yang terletak dekat dengan Jalan A.yani dan Jalan MT. Haryono dijadikan parkir untuk kendaraan modor dan mobil serta dikelola untuk ruang terbuka hijau. Perletakan massa bangunan condong ke arah barat daya dan tenggara karena tingkat kebisingan rendah serta menyesuaikan peraturan pemerintah (lihat Gambar 2).

Konsep Orientasi (poin 3) utama bangunan menghadap ke arah Jalan A. Yani karena merupakan Jalan utama dan sering dilalui kendaraan, serta memiliki akses yang mudah menuju ke bangunan. Selain itu, berpotensi dari segi view from site dan view to site. Kemudian adanya kegiatan rutin car free day yang terjadi di Jalan A. Yani juga menjadi pertimbangan dalam penempatan orientasi bangunan menghadap ke Jalan. Selain itu orientasi bangunan juga menghadap ke arah Jalan MT. Haryono dengan pertimbangan Jalan berpotensi dilalui pengunjung dan orientasi sekitar bangunan juga mengarah ke Jalan MT. Haryono, namun orientasi ini berada pada sisi barat sehingga akan menggunakan shading dan vegetasi untuk mereduksi panas (lihat Gambar 2).

Konsep vegetasi (poin 4) pada tapak yakni vegetasi yang sebelumnya terdapat dalam site akan ditebang, kemudian pada arah Jalan A. Yani akan diberikan vegetasi pengarah dan vegetasi buffer untuk menyaring pulusi serta mereduksi kebisingan. area yang terkena panas matahari sore diberi vegetasi peneduh dan Vegetasi pengarah karena terletak di Jalan MT. Haryono. Area yang berhadapan dengan dinding bangunan Sekolah Stella Marisa akan diberi vegetasi pengarah dan peneduh. Perletakan vegetasi peneduh akan ditempatkan pada area yang membutuhkan seperti parkiran, taman dan public space (lihat Gambar 2).

Zonasi tapak (poin 5) terdiri dari ruang yang bersifat publik, semi pubik, privat, semi privat dan servis. Area yang dekat dengan Jalan akan diperuntukkan bagi area publik karena sifatnya yang mudah diakses oleh umum, kemudian area semi publik diletakkan dekat dengan area publik karena memiliki korelasi ruang. Area semi privat dan privat diletakkan ditengah bangunan dengan pertimbangan menghindari kebisingan, kemudian area paling belakang bangunan diletakkan sebagai area servis. Gambar konsep tapak dapat dilihat pada Gambar 2.

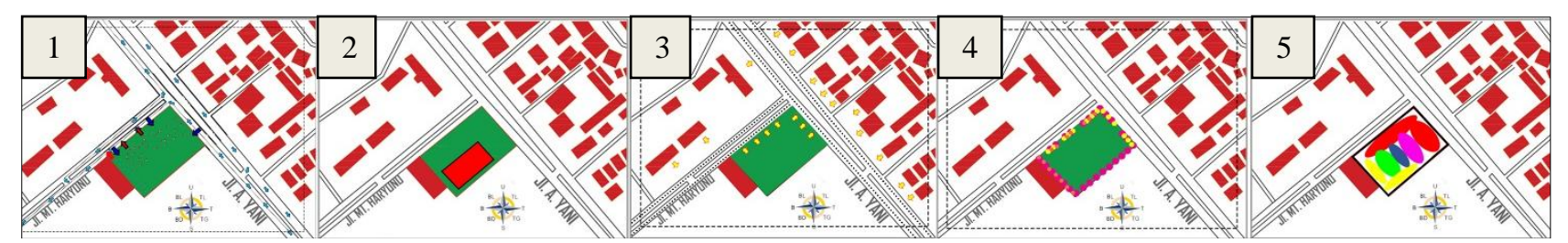

Gambar 2. Konsep Tapak Youth Center di Kota Pontianak

Sumber: Penulis, 2020

Analisa bentuk merupakan analisis yang dilakukan terhadap pola dari transformasi bentuk, transformasi didasarkan pada perubahan yang terjadi pada bentukan dasar hingga mencapai bentukan akhir yang ditetapkan. Youth Center merupakan sarana pendidikan non formal sehingga menekankan pada bentuk yang fungsional dan efektif. Kemudian pertimbangan lain yakni faktor karakter remaja yang bebas dan aktif sehingga perlu adanya ruang yang memiliki fungsi ganda dan dapat 
memberikan keleluasan pada penggunanya. Kemudian selain memperhatikan ruang-ruang dalam, perlu memperhatikan ruang luar sebagai pendukung bangunan untuk menciptakan efisiensi pemanfaatan tapak, sehingga bentuk bangunan perlu memperimbangkan kegiatan yang membutuhkan space pada area luar bangunan. Analisa bentuk dapat dilihat pada Gambar 3.

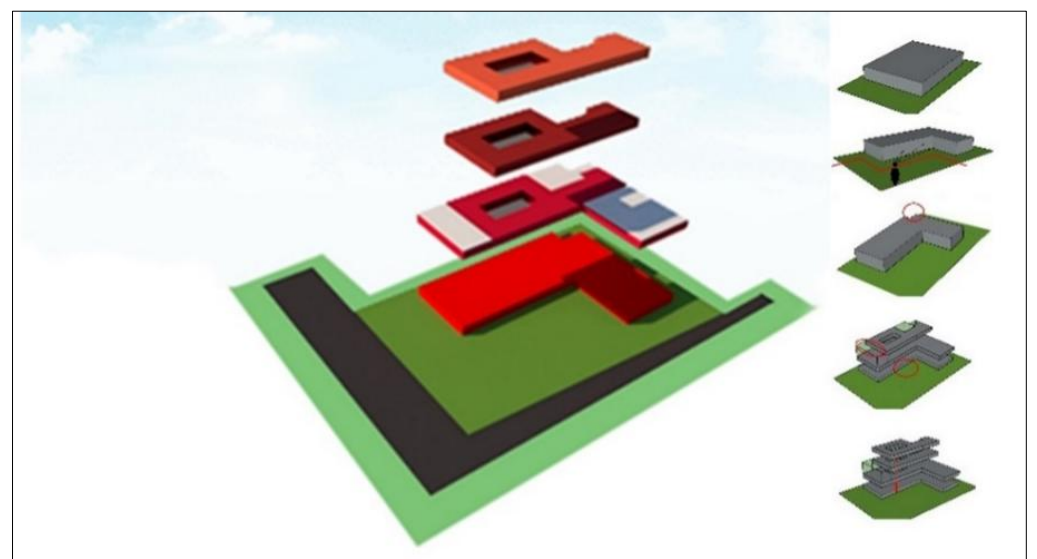

Gambar 3. Analisa Bentuk Youth Center di Kota Pontianak Sumber: Penulis, 2020

Gubahan bentuk terdiri dari dua massa bangunan, massa bangunan utama terdiri dari empat lantai sedangkan massa bangunan kedua terdiri dari dua lantai. Pada sisi bangunan terdapat fasad sebagai estetika dan shading, menggunakan atap pelana sebagai penyesuaian terhadap iklim tropis, terdapat atap kaca untuk masuknya cahaya, penggunaan dinding kaca untuk masuk cahaya serta menciptakan ruang yang terkesan luas. Entrance utama masuk ke bangunan terletak ditengah bangunan dengan pertimbangan mudah dilihat dan mudah dijangkau. Untuk lebih jelasnya dapat dilihat pada Gambar 4.

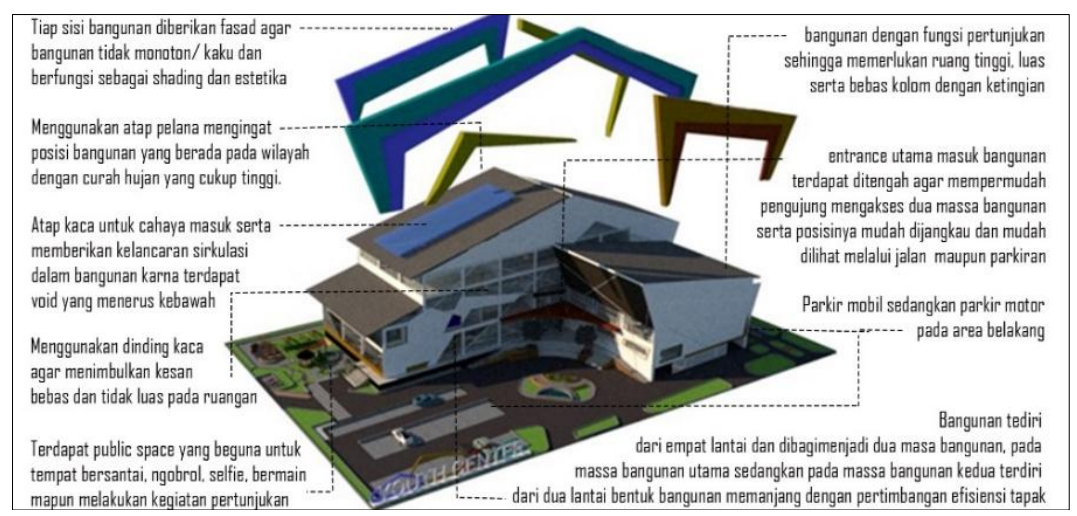

Gambar 4. Gubahan Bentuk Youth Center di Kota Pontianak

Sumber: Penulis, 2020

Konsep struktur bangunan Youth Center di Kota Pontianak terbagi menjadi dua yaitu struktur bawah dan struktur atas, adapun struktur bawah menggunakan pondasi jenis tiang pancang dengan sistem tidak langsung, struktur atas yaitu pada lantai menggunakan sistem pelat dan beton dengan penutup lantai menggunakan material homogeneoustile dan keramik, struktur rangka menggunakan beton bertulang dengan dinding bata ringan, kemudian plafond pada bangunan menggunakan material GRC selain itu untuk atap menggunakan struktur space frame. Lebih jelas dapat dilihat pada gambar 9. 


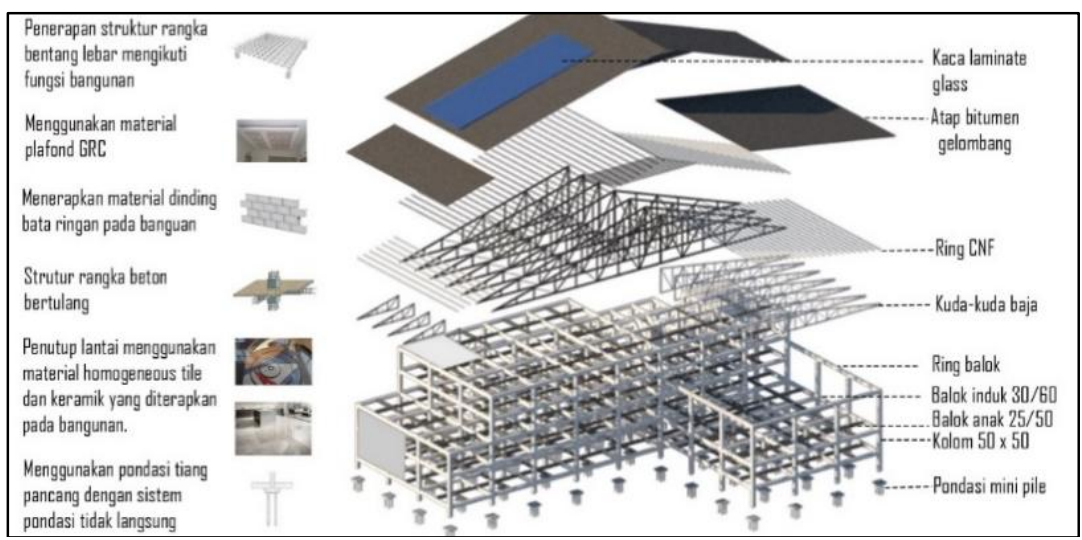

Gambar 5. Konsep Struktur Youth Center di Kota Pontianak

Sumber: Penulis, 2020

Analisa utilitas pada bangunan Youth Center di Kota Pontianak terdiri dari sistem jaringan air, jaringan listrik, informasi dan komunikasi, CCTV, sistem tata udara, sistem keamanan, dan sistem transportasi bangunan.

Sistem jaringan air terdiri dari sistem jaringan air bersih dan sistem jaringan air kotor. Jaringan air bersih menggunakan sumber air PDAM dengan sistem up feed dan down feed. Kebutuhan air bersih dihitung melalui penggunaan air bersih keseharian dan air bersih untuk hidran, total air bersih yang dibutuhkan yaitu $181.830 \mathrm{~m}^{3}$. Bangunan Youth Center menggunakan tangka air dan ground tank untuk menampung air bersih. Untuk sistem air kotor, limbah padat dari lavatory disalurkan melalui pipa ke septic tank, kemudian limbah cair akan disalurkan ke perangkap sabun. Untuk limbah dari cafetaria akan disalurkan ke grace trap. Nantinya limbah akan disalurkan ke STP untuk diolah sebelum ke riol kota. Adapun luas yang diperlukan untuk menentukan dimensi septic tank yaitu $122.4 \mathrm{~m}^{3}$.

Jaringan listrik bersumber dari PLN serta dari generator set sebagai sumber listrik cadangan, adapun total daya listrik yang diperlukan untuk bangunan Youth Center yaitu $960 \mathrm{kw}$. Sistem tata suara yang digunakan bersumber pada speaker selector yang nantinya akan terhubung dengan item pemutaran musik, sedangkan untuk jaringan komunikasi menggunakan jaringan internet. Jaringan CCTV menggunakan menggunakan CCTV jenis Hawk Eye dan CCTV 7k. kemudian sistem tata udara pada bangunan Youth Center di Kota Pontianak menggunakan sistem AC sentral jenis VRV, dengan perletakan pada ruang seminar, ruang pengelola, aula serbaguna dan ruang kelas.

Sistem keamanan bangunan Youth Center di Kota Pontianak menggunakan hidran halaman, jumlah hidran halaman yaitu 7 buah dengan perhitungan diletakkan 1 buah tiap 1000m, PAR/ Fire Extingguisher, detector asap, sprinkler dan Fire Suppression System. Kemudian sistem transportasi pada bangunan menggunakan tangga, ramp dan lift dengan pertimbangan ketinggian bangunan mencapai empat lantai.

Analisis konsep fisika bangunan terdiri tiga aspek yaitu pencahayaan, akustika dan penghawaan. Pada pencahayaan aspek untuk memasukkan cahaya kedalam ruangan menggunakan skylight dan penerapan dinding kaca sedangkan untuk antisipasi panas cahaya matahari sore menggunakan secondary skin dan penggunaan vegetasi. Untuk penghawaan pada bangunan menggunakan AC VRV pada ruang tertentu serta penerapan void dan ventilasi agar terjadi pergerakan udara. Kemudian untuk meminimalisir kebisingan terkait akustika, dinding menggunakan material bata ringan serta penggunaan Glasswool pada ruang studio musik.

\section{Hasil Perancangan}

Hasil gambar pra-rancangan Youth Center di Kota Pontianak meliputi gambar site plan, gambar denah yang terdiri dari empat lantai, gambar tampak, gambar potongan, suasana interior dan eksterior bangunan. Gambar site planmemperlihatkan akses masuk ke bangunan serta kondisi dalam tapak. 
Terdapat tiga entrance masuk dan keluar bangunan, akses bangunan terdiri dari akses untuk kendaraan mobil dan motor. Akses masuk kendaraan mobil terdapat pada Jalan A. Yani dan Jalan MT. Haryono sedangkan akses keluar terdapat pada Jalan MT. Haryono. Parkir mobil terletak pada area depan bangunan yaitu area Jalan A. Yani dan Jalan MT. Haryono kemudian parkir motor terletak pada area belakang bangunan. Pada area depan bangunan terdapat area parkir motor ojek online yang letaknya di luar tapak. Pada area yang dekat Jalan A. Yani terdapat public space meliputi area bermain jungkat-jungkit dan ayunan, track sepeda outdoor, area pertunjukan serta area bersantai dilengkapi dengan kursi dan meja. Kemudian untuk area servis seperti ruang genset, septic tank dan perangkap sabun terletak di area belakang bangunan (selatan) sedangkan untuk ground tank terdapat di area dekat dengan Jalan MT. Haryono. Analisa site plan dapat dilihat pada Gambar 6.

Pertimbangan perletakan area parkir mobil maupun parkir motor dekat dengan jalan agar lebih mudah dicapai karena akses yang dekat dengan jalan utama, area public space diletakkan dekat dengan Jalan A. Yani agar dapat menjadi daya tarik pada bangunan. Kemudian perletakan area servis pada belakang bangunan dilakukan agar tidak menganggu estetika serta mudah dalam pengontrolan karena terletak pada satu zona. Adapun gambar site plan dapat dilihat pada Gambar 6.

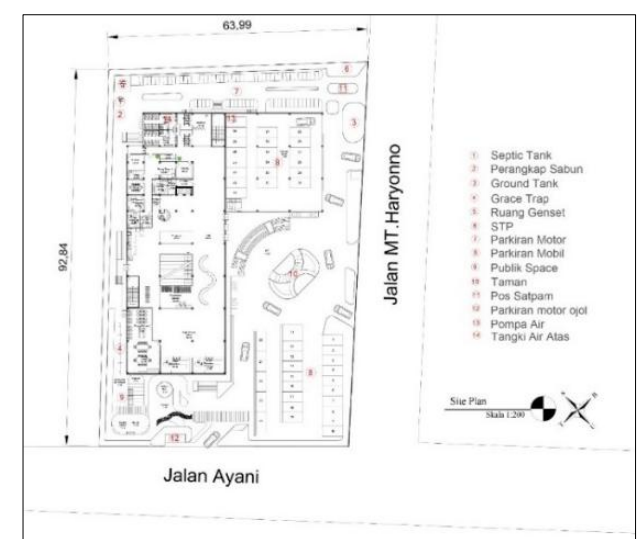

Gambar 6. Site plan Bangunan Youth Center di Kota Pontianak Sumber: Penulis, 2020

Gambar denah Youth Center terdiri dari empat lantai. Lantai dasar yang dimanfaatkan sebagai area parkiran mobil yang terletak dibawah ruang seminar pada lantai satu, terdapat akses menuju lantai satu dari lantai dasar menggunakan transportasi tangga (lihat gambar 7).

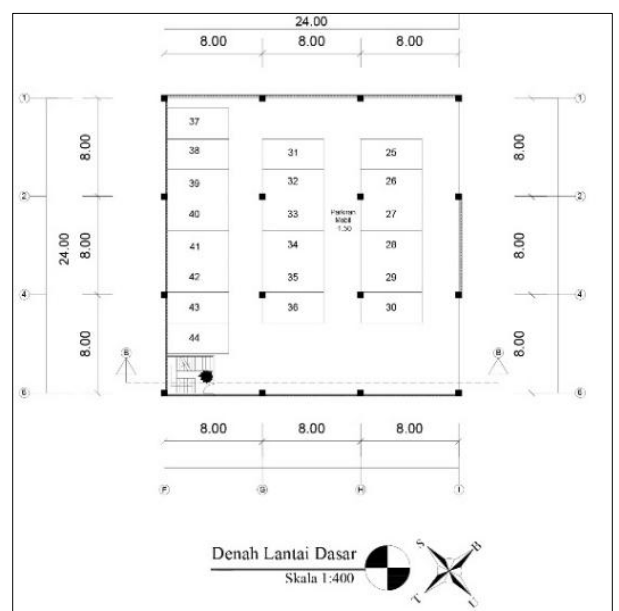

Gambar 7. Denah Lantai Dasar Bangunan Youth Center di Kota Pontianak Sumber: Penulis, 2020 
Denah lantai satu menunjukkan merupakan lantai dengan fungsi yang lebih publik, ditandai dengan adanya ruang-ruang yang bersifat umum. Terdapat retail souvenir, ruang pengelola, ruang untuk remaja yang akan belajar desain, terdapat ruang seminar yang dapat disewakan kepada pengunjung dan terdapat kontemporer kecil sehingga pada lantai satu remaja dapat melakukan pertunjukan kecil sehingga mudah dilihat pengunjung. Terdapat dua entrance masuk ke bangunan yaitu pada bagian tengah dan belakang bangunan. Denah lantai satu dapat dilihat pada Gambar 8 .

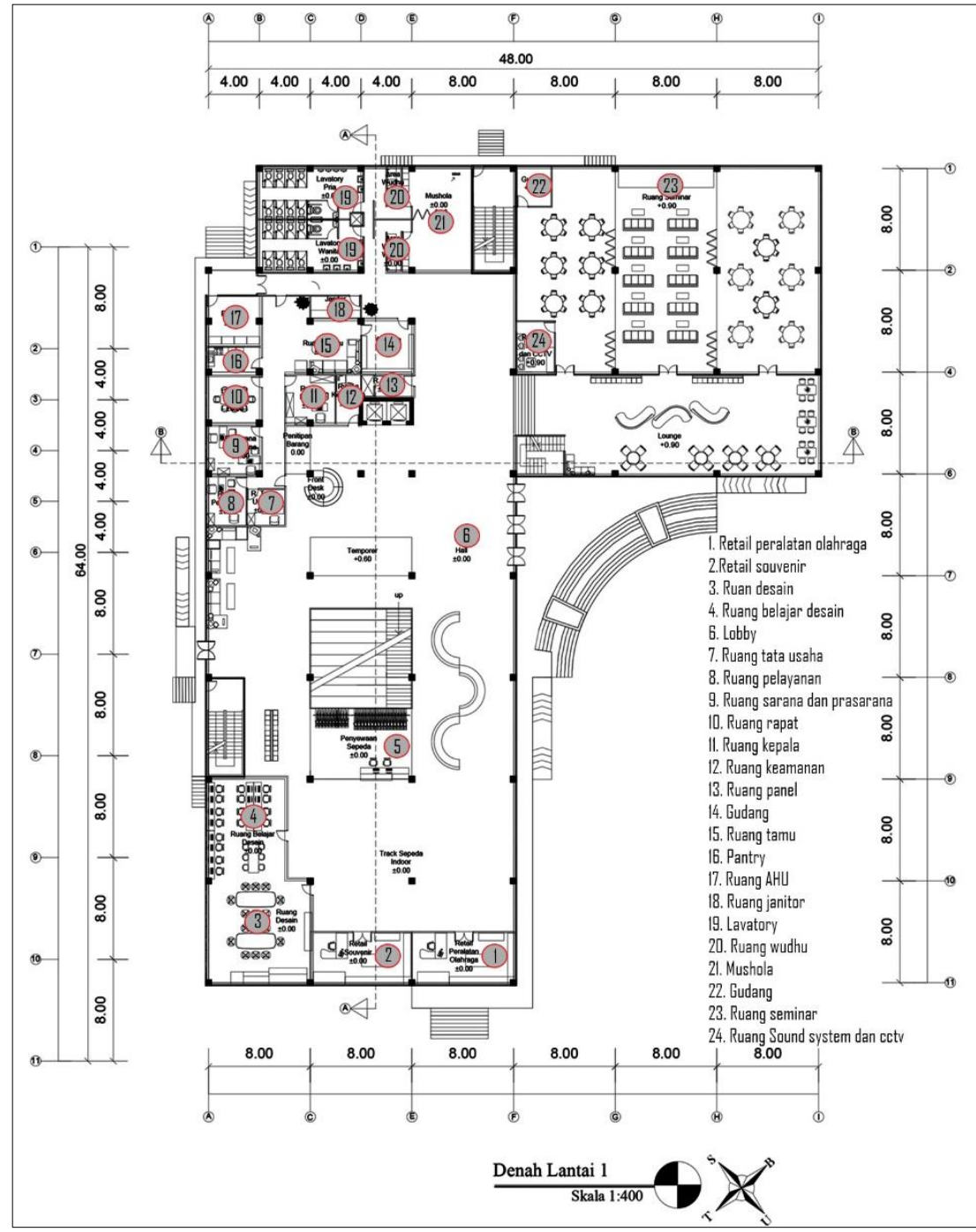

Gambar 8. Denah Lantai Satu Bangunan Youth Center di Kota Pontianak Sumber: Penulis, 2020

Gambar denah lantai dua menunjukkan fungsi ruang yang bersifat kreatif dan rekreatif dengan penerapan ruang-ruang olahraga yang berguna untuk meningkatkan skill remaja. selain itu terdapat ruang Aula Serbaguna yang berguna sebagai wadah remaja berlatih tari, sastra, teater serta remaja dapat melakukan pementasan ataupun pertunjukan yang dapat ditonton oleh pengunjung. Gambar denah lantai dua dapat dilihat pada Gambar 9. 


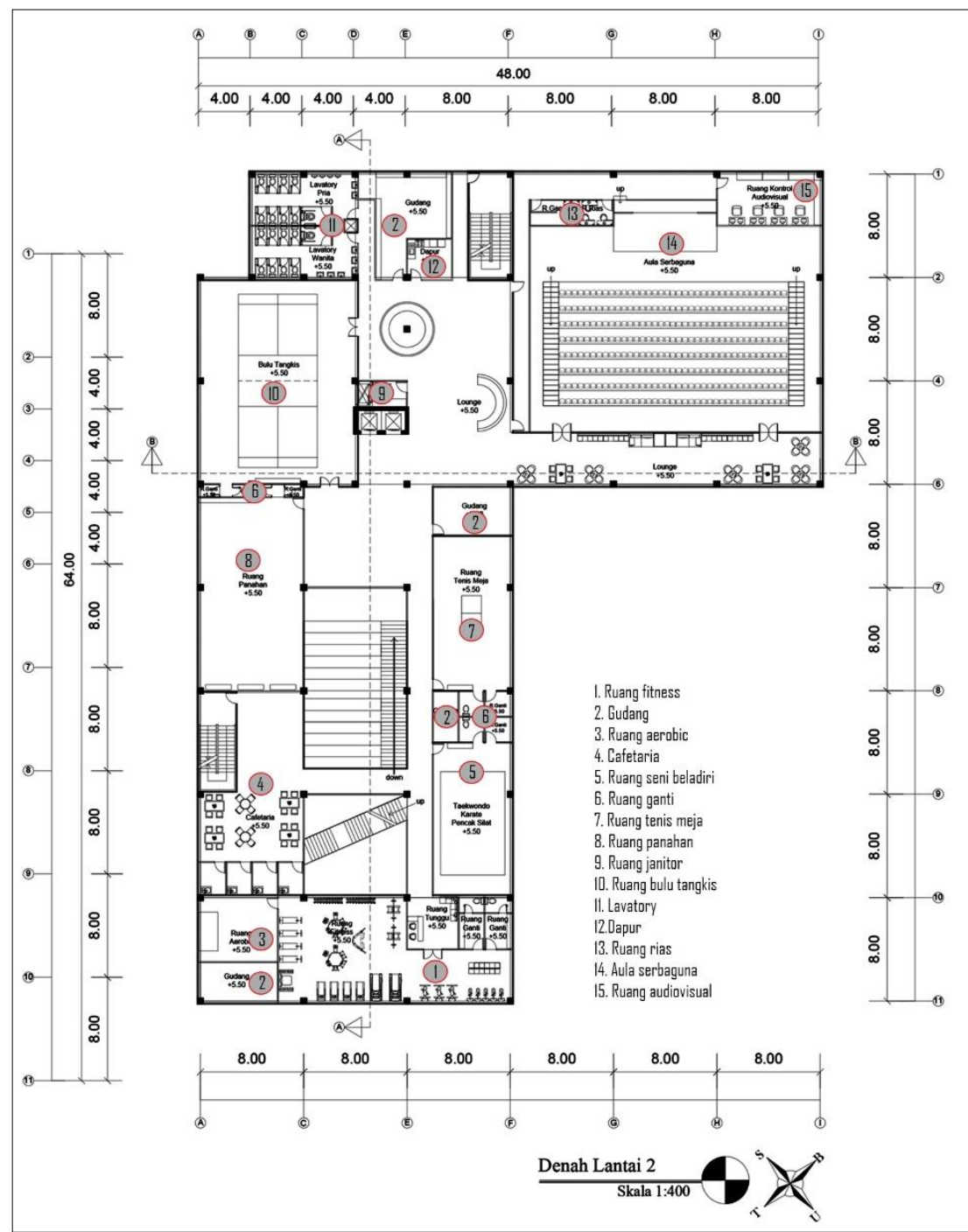

Gambar 9. Denah Lantai Dua Bangunan Youth Center di Kota Pontianak Sumber: Penulis, 2020

Denah lantai tiga terdiri dari ruang-ruang dengan fungsi rekreatif, ruang yang terdapat pada lantai tiga didominasi oleh area bermain seperti area trampoline, panjat tebing, outbond, permainan biliar dan ruang studio musik. Perletakan studio musik pada lantai tiga dilakukan dengan pertimbangan tingkat kebisingan relatif tidak menganggu karena berada pada area yang tidak memerlukan tingkat kebisingan yang rendah. Denah lantai tiga dapat dilihat pada Gambar 10. 


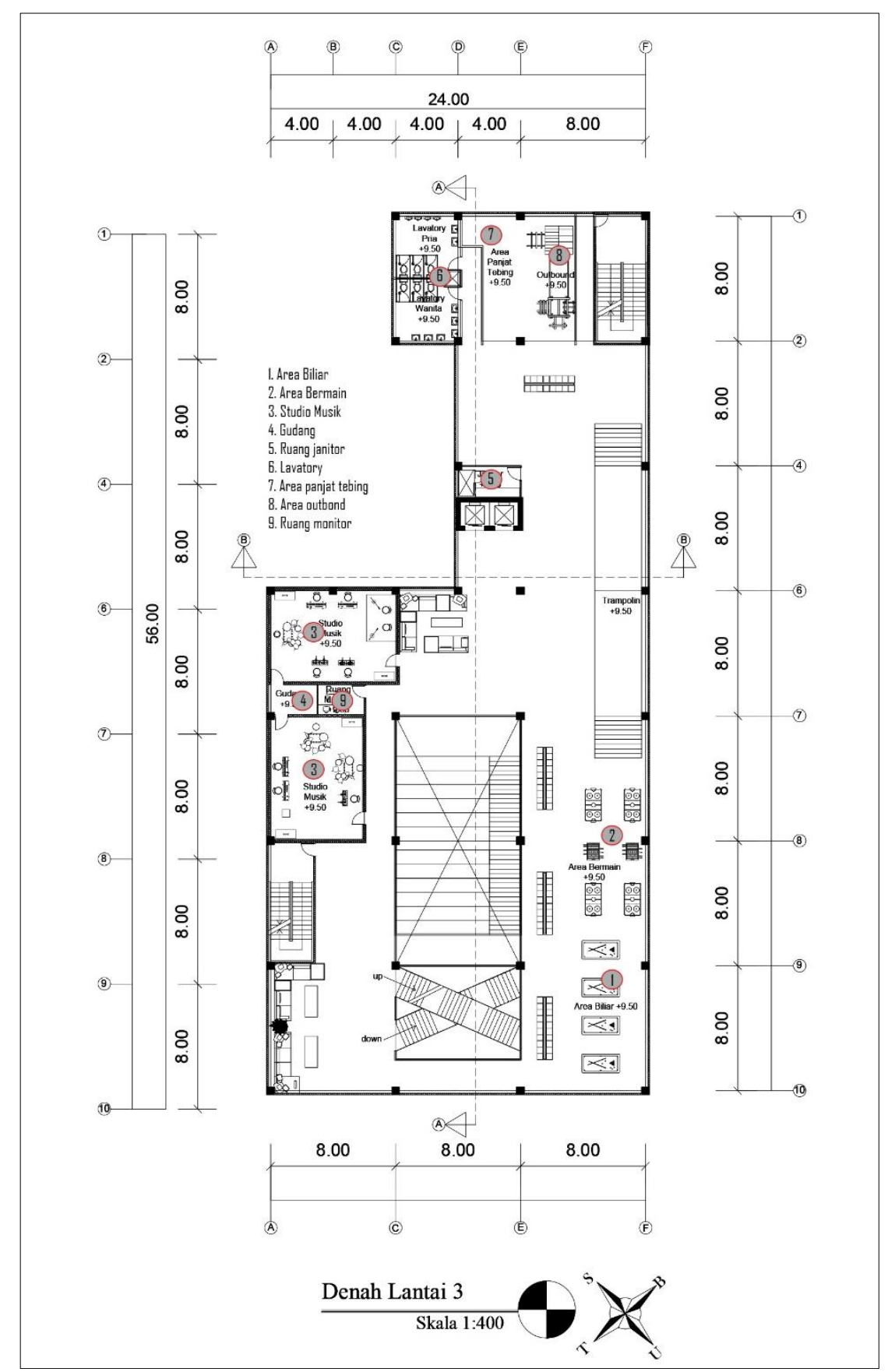

Gambar 10. Denah Lantai Tiga Bangunan Youth Center di Kota Pontianak Sumber: Penulis, 2020

Denah lantai empat merupakan lantai terakhir dalam bangunan, ruang-ruang yang terdapat pada lantai empat merupakan ruang dengan fungsi edukatif sehingga sifatnya lebih privat dengan tingkat kebisingan yang rendah. Adapun ruang-ruang yang terdapat pada lantai empat yaitu ruang kelas, ruang konseling, studio fotografi serta area computer, belajar dan perpustakaan yang bersifat open space sehingga memungkinkan remaja untuk bersosialisasi dan berdiskusi dengan mudah. Denah lantai empat dapat dilihat pada Gambar 11. 


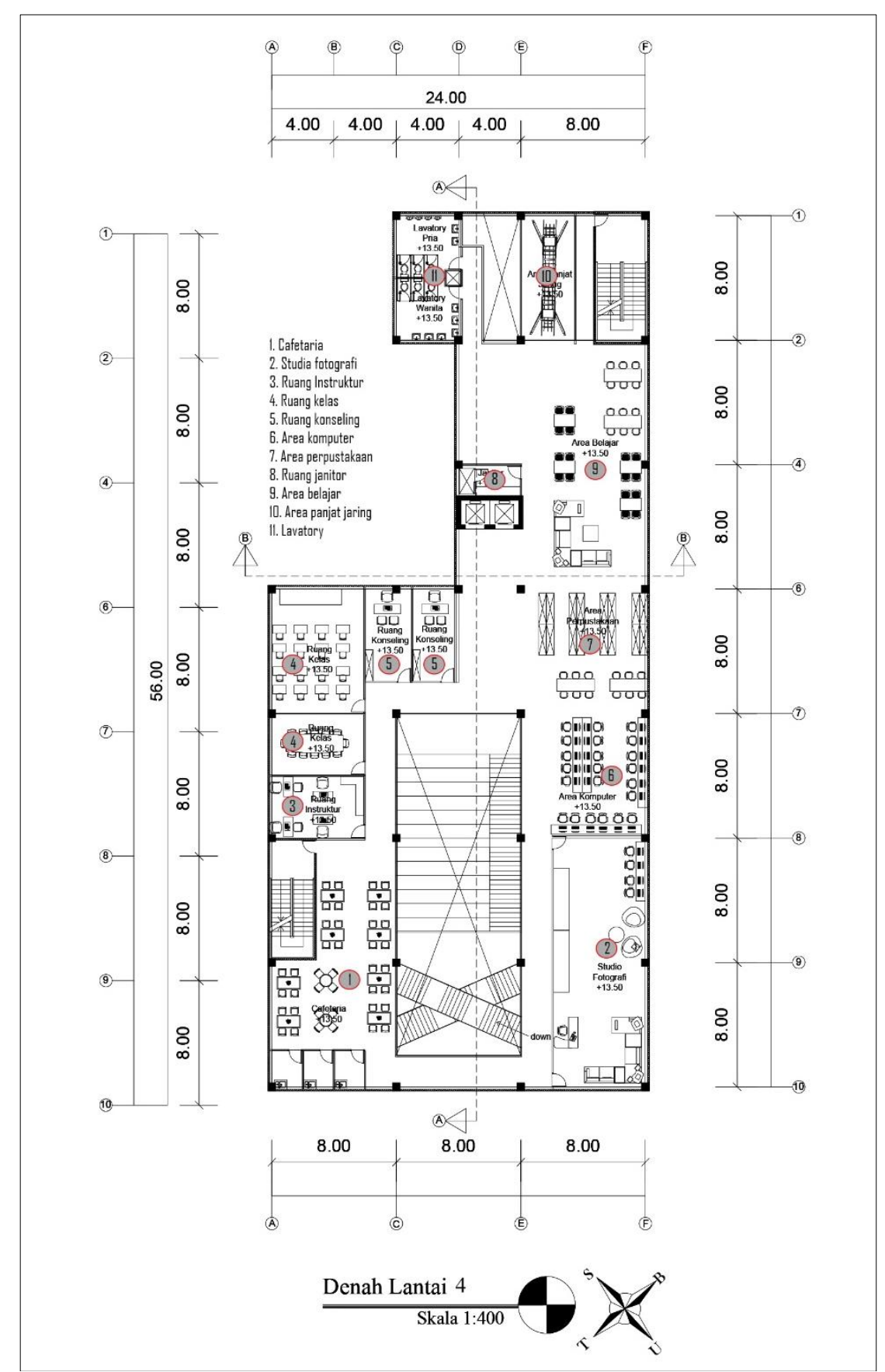

Gambar 11. Denah Lantai Empat Bangunan Youth Center di Kota Pontianak Sumber: Penulis, 2020

Gambar tampak pada bangunan menunjukkan penggunaan warna pada fasade bangunan dibuat menyerupai karakter remaja yang tidak menyukai sesuatu yang formal dan kaku sehingga remaja dapat tertarik untuk mengunjungi bangunan. Menggunakan atap kaca sebagai media masuk cahaya serta untuk kelancaran sirkulasi dalam bangunan. Atap bangunan berbentuk pelana dengan perpaduan atap dak pada bagian entrance masuk bangunan, penggunaan dinding kaca menciptakan ruang yang terkesan luas serta sebagai media cahaya masuk. Gambar tampak dapat dilihat pada Gambar 12. 


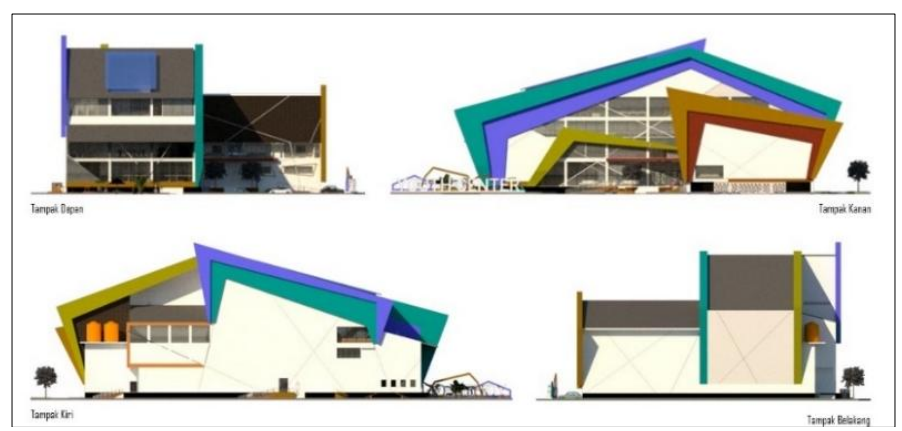

Gambar 12. Tampak Bangunan Youth Center di Kota Pontianak Sumber: Penulis, 2020

Gambar potongan bangunan Youth Center di Kota Pontianak menampilan struktur maupun konstruksi yang digunakan. Struktur yang digunakan yaitu beton bertulang dengan konstruksi atap menggunakan jenis atap miring. Terdapat perbedaan lantai pada massa bangunan yakni pada massa bangunan dua merupakan ruang aula serbagunan sehingga memerlukan ruang yang bebas kolom serta memiliki atap yang tinggi, sedangkan pada massa bangunan satu merupakan bangunan utama yang memuat banyak ruang sehingga dimensi bangunan lebih tinggi serta agar terjadi pergerakan sirkulasi udara pada bangunan. Gambar potongan dapat dilihat pada Gambar 13.

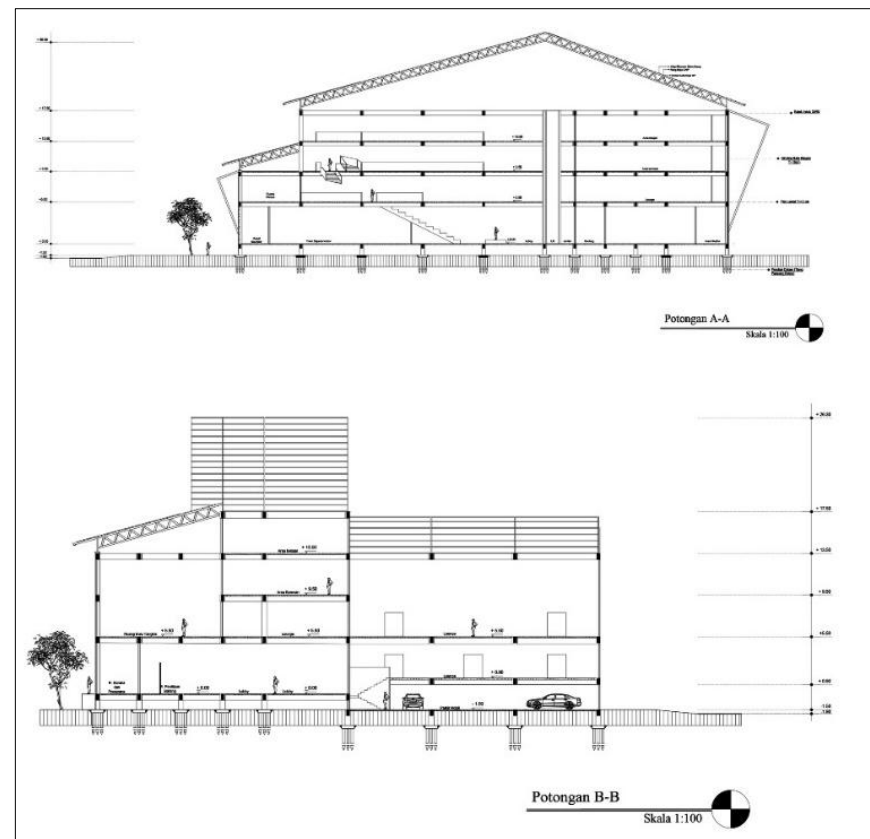

Gambar 13. Potongan Bangunan Youth Center di Kota Pontianak Sumber: Penulis, 2020

Gambar eksterior menunjukan korelasi antara tapak terhadap parkiran, taman, public space serta menunjukan keadaan sekitar site. Gambar interior bangunan menunjukan perletakan perabot, pergerakan sirkulasi serta penggunaan warna pada ruang. Perancangan Youth Center berfungsi sebagai wadah yang dapat membina dan mengembangkan potensi remaja dengan fungsi edukatif, kreatif dan rekreatif. Fungsi tersebut terealisasi dalam ruang seperti ruang edukatif berupa ruang seminar (poin C), kreatif dan rekreatif pada ruang olahraga (poin E), kemudian ruang-ruang untuk duduk (poin A dan D), serta penerapan ruang yang luas sehingga sewaktu-waktu dapat dimanfaatkan untuk suatu kegiatan (poin B dan F). Area luar bangunan menampilkan suasana pada fasad mengikuti karakter remaja, dengan penerapan warna warna cerah untuk menarik perhatian remaja (poin G, I dan J), kemudian terdapat area public space sebagai tempat remaja bersantai, mengobrol dan berdiskusi. 


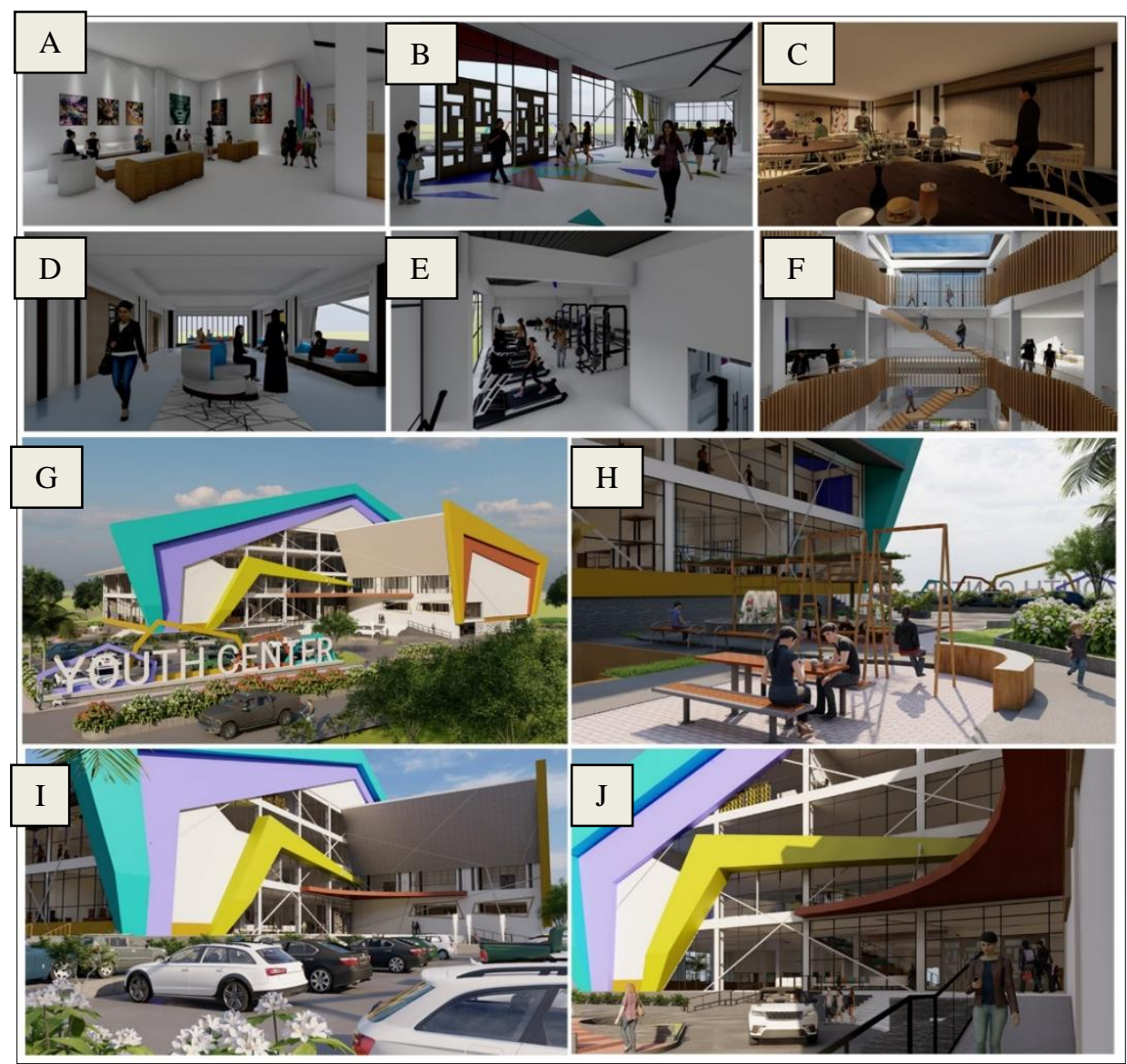

Gambar 14. Suasana Bangunan Youth Center di Kota Pontianak Sumber: Penulis, 2020

\section{Kesimpulan}

Perancangan Youth Center di Kota Pontianak ini memperhatikan karakteristik remaja serta fungsi bangunan. Youth Center ini merupakan wadah bagi remaja untuk mengembangkan potensinya diluar pendidikan formal dengan menerapkan fungsi edukatif, kreatif dan rekreatif. Fungsi edukatif berguna untuk mengembangkan ilmu pengetahuan remaja diwujudkan dengan penerapan area belajar, perpustakaan, area computer maupun ruang-ruang kelas. Kemudian fungsi kreatif merupakan pengembangan remaja dalam bidang keterampilan, hal ini diwujudkan dengan adanya ruang aula serbaguna untuk Latihan maupun pertunjukan seni, area belajar desain, dan ruang-ruang olahraga. Sedangkan untuk fungsi rekreatif lebih berorientasi pada pemanfaatan waktu luang dengan mengikuti kegiatan yang menyenangkan atau bersifat resfeshing, fungsi ini diwujudkan dengan adanya area bermain.

\section{Ucapan Terima Kasih}

Ucapan syukur kepada Tuhan Yang Maha Esa, kepada kedua orang tua dan keluarga atas motivasi secara langsung maupun tidak langsung. Kepada para dosen pembimbing Proyek Tugas Akhir yaitu Bontor Jumaylinda BR Gultom, S.T., M.T. selaku pembimbing utama dan Emilya Kalsum, S.T., M.T. selaku pembimbing pendamping yang telah memberikan kritik dan saran untuk penulis. Kepada teman-teman yang telah memberikan doa dan dukungan dalam pengerjaan Proyek Tugas Akhir ini, penulis mengucapkan terima kasih sebesar-besarnya. 


\section{Daftar Acuan}

Ahmadi, A., Uhbiyati, N. (2001). Ilmu Pendidikan. Jakarta: PT Rineka Cipta

Argiati, S.H.B. (2008). Perilaku Agresif Ditinjau dari Persepsi Pola Asuh Authoritarian, Asertivitas dan Tahap Perkembangan Remaja Pada Anak Binaan Lembaga Pemasyarakata Anak Kutoarjo, Jawa Tengah, Tesis, tidak diterbitkan, Yogyakarta: Pascasarjana UGM

Bappenas. (2013). Proyeksi Penduduk Indonesia Indonesia Population Projection 2010-2035. Jakarta: Bappenas

BNN Provinsi Kalimantan Barat. (2019, October 16). Data Penyimpangan yang terjadi pada Remaja Kota Pontianak. Retrieved from https://bnn.go.id/dosen-mahasiswa-kalimantan-barat-jadi-penggiat-anti-narkoba/

Gunarsa, S.D. (1982). Dasar dan Teori Perkembangan Anak. Jakarta: BPK Gunung Mulya

Gunarsa, S.D., Gunarsa, Y.S. (2001). Psikologi Praktis: Anak, Remaja dan Keluarga, hlm 77. Jakarta: BPK Gunung Mulia.

Hurlock, E. B. (1990). Psikologi Perkembangan: Suatu Pendekatan Sepanjang Rentang Kehidupan. Jakarta: Erlangga

Jatmika, S. (2010). Genk Remaja, Anak Haram Sejarah ataukah Korban Globalisasi?. hlm. 10-11. Yogyakarta: Kanisius

Kartono, K. (2006). Kenakalan Remaja. Jakarta: Raja Grafindo Persada

Kementerian Pemuda dan Olahraga Republik Indonesia. (1989). Pedoman Penyelenggaraan Gelanggang Remaja. Jakarta: Kementerian Pemuda dan Olahraga Republik Indonesia

Krori, S.D. (2011). DevelopmentalPsycholog, dalamHomeopathic Journal:4(3)

Lewin, K. (1946). "Behavior and development as a function of the total situation"Manual of Child Development L. Carmichael (ed.). New York: John Willey

Media Indonesia. (2018, May 6). Indonesia Diprediksi Jadi Kekuatan Ekonomi Terbesar Keempat pada 2050. Retrieved from https://mediaindonesia.com/ekonomi/159092/indonesia-diprediksi-jadi-kekuatan-ekonomi-terbesar-keempatpada-2050

Pemerintah Daerah Kota Pontianak. (2013). Peraturan Daerah Kota Pontianak Nomor 2 Tahun tentang Rencana Tata Ruang Wilayah Kota Pontianak Tahun 2013-2033. Pontianak: Pemerintah Daerah Kota Pontianak

Pemerintah Daerah Kota Pontianak. (2018). Peraturan Daerah Kota Pontianak Nomor 3 Tahun 2018 Tentang Perubahan Atas Peraturan Daerah Nomor 12 Tahun 2009 Tentang Penyelenggaraan Pendidikan Di Kota Pontianak. Pontianak: Pemerintah Daerah Kota Pontianak

Sarwono, S.W. (2004). Psikologi Remaja. Jakarta: CV Rajawali

Suwarni, L. (2009). Monitoring Parental dan Perilaku Teman Sebaya Terhadap Perilaku Seksual Remaja SMA Di Kota Pontianak. Jurnal Promosi Kesehatan Indonesia Universitas Diponogoro

Tim Penyusun Kamus Pusat Bahasa. (1991). Kamus Lengkap Bahasa Indonesia, Jakarta: Balai Pustaka

Tim Penyusun Kamus Pusat Bahasa. (2008). Kamus Besar Bahasa Indonesia. Jakarta: Pusat Bahasa

World Health Organization. (1974). World Health Organization. Switzerland: AV. Appia, 1211 Geneva 27 